\title{
Sex differences in the cardiac cholinergic response to adrenalin-induced myocardial necrosis and light desynchronosis
}

\author{
M. R. Khara ${ }^{\mathbb{D} * A, C, F}$, H. O. Bezkorovaina ${ }^{B, C, D}$, I. M. Klishch ${ }^{\mathbb{E}}$, V. Ye. Pelykh ${ }^{B}$ \\ Ivan Horbachevsky Ternopil National Medical University of the Ministry of Health of Ukraine
}

A - research concept and design; B - collection and/or assembly of data; C - data analysis and interpretation; D - writing the article;

$\mathrm{E}$ - critical revision of the article; $\mathrm{F}$ - final approval of the article

Key words: necrosis, chronobiology disorders,

cholinergic receptors, vagus nerve, sex.

Pathologia 2020; 17 (2), 142-148

*E-mail: khara m@ukr.net

The aim was to identify sex differences in the cardiac response to cholinergic stimuli in the development of myocardial necrosis and light desynchronosis.

Materials and methods. Experiments were conducted in 144 albino rats (72 males, 72 females). Myocardial necrosis was induced by adrenaline $(0.5 \mathrm{mg} / \mathrm{kg}$, intramuscularly).

The intensity of bradycardia that occurred as a response to intravenous acetylcholine injection and electrical stimulation of vagus nerve was measured. The animals were divided into 4 groups: 1 - rats that were in a light balance (day/night); 2 - rats exposed to light deprivation for 10 days; 3 - rats exposed to permanent lighting for 10 days; 4 - animals exposed to permanent lighting for 10 days and injected with melatonin $(5 \mathrm{mg} / \mathrm{kg})$ intraperitoneally 1 hour before the necrosis modeling.

Results. The development of myocardial necrosis when occurring in light deprivation was characterized by an increased responsiveness of the rat heart to cholinergic stimulation due to an increase in both cholinoreceptors sensitivity and release of acetylcholine from the vagus nerve terminals in females, and due to only an increased cholinoreceptors sensitivity in males. The development of myocardial necrosis in rats exposed to permanent lighting was characterized by significantly higher sensitivity of cholinergic structures of the heart than that in light balance, especially in females. Melatonin injection in the development of myocardial necrosis contributed to the heart cholinergic structures response to the stimulation, which was close to that observed in conditions of light balance, though it remained somewhat higher: due to the facilitation of acetylcholine release from vagus nerve in females, and it was combined with a higher sensitivity of cholinoreceptors in males.

Conclusions. The development of myocardial necrosis in light desynchronosis (light deprivation or permanent lighting) causes an increased heart response to cholinergic stimulation in rats. Such effects are stronger, especially in females in conditions of permanent lighting. The injection of melatonin in rats with myocardial necrosis and permanent lighting results in an approximation (but not restoration) of the heart sensitivity to cholinergic stimuli parameters to those that are observed in light balance. However, the heart response to cholinergic stimulation remains higher, especially in males.

Ключові слова: некроз міокарда, світловий Аесинхроноз, чутливість холінорецепторів, n. vagus, стать.

Патологія. 2020.

T. 17, № 2(49).

C. $142-148$

\section{Статеві відмінності холінергічних кардіальних реакцій при розвитку адреналін-індукованого некрозу міокарда на тлі світлового десинхронозу}

\section{М. Р. Хара, Г. О. Безкоровайна, І. М. Кліщ, В. Є. Пелих}

Мета роботи - встановити статеві відмінності реагування серця на холінергічні стимули під час розвитку некрозу міокарда на тлі світлового десинхронозу.

Матеріали та методи. Досліди виконали на 144 щурах-альбіносах (72 самці, 72 самиці). Некроз міокарда викликали введенням адреналіну (0,5 мг/кг внутрішньом'язово). Визначали інтенсивність брадикардії, що виникала під час внутрішньовенного введення ацетилхоліну та електричної стимуляції n. vagus. Тварин поділили на 4 групи: 1 - щури, які перебували в умовах світлового балансу (день/ніч); 2 - щури, які 10 днів перебували в умовах світлової депривації; 3 - щури, які 10 днів перебували в умовах перманентного освітлення; 4 - тварини, які 10 днів перебували в умовах перманентного освітлення, але за 1 годину до моделювання некрозу отримували мелатонін (5 мг/кг внутрішньочеревно).

Результати. Під час розвитку некрозу міокарда на тлі світлової депривації реакція серця щурів на холінергічні впливи збільшувалася: в самиць - завдяки збільшенню чутливості холінорецепторів і вивільнення більшої кількості ацетилхоліну з закінчень $\mathrm{n}$. vagus, а в самців - тільки внаслідок збільшення чутливості холінорецепторів. Розвиток некрозу міокарда в умовах перманентного освітлення характеризувався суттєвішою, ніж за світлового балансу, чутливістю холінергічних структур серця, особливо в самиць. Застосування мелатоніну сприяло тому, що при розвитку некрозу міокарда реакція холінергічних структур серця на стимуляцію наближалася до зареєстрованої в умовах світлового балансу, хоча й залишалася дещо більшою: у самиць - унаслідок полегшеного вивільнення ацетилхоліну з n. vagus, а в самців поєднувалася з більшою чутливістю холінорецепторів.

Висновки. Розвиток некрозу міокарда на тлі світлового десинхронозу (світлова депривація чи перманентне освітлення) викликає посилення реагування серця щурів на холінергічну стимуляцію. Суттєвішими такі ефекти є в умовах перманентного освітлення, особливо в самиць. Застосування мелатоніну під час моделювання некрозу міокарда на тлі перманентного освітлення забезпечує наближення (але не відновлення) параметрів, що характеризують чутливість серця до холінергічних стимулів, до зареєстрованих в умовах світлового балансу. Реакція серця на холінергічну стимуляцію залишається дещо більшою, особливо в самців. 


\section{Половые отличия холинергических кардиальных реакций при развитии адреналин-индуцированного некроза миокарда на фоне светового десинхроноза}

\section{М. Р. Хара, Г. А. Безкоровайная, И. Н. Ккищ, В. Е. Пелых}

Цель работы - установить половые отличия реагирования сердца на холинергические стимулы при развитии некроза миокарда на фроне светового десинхроноза.

Материалы и методы. Опыты провели на 144 крысах-альбиносах (72 самца, 72 самки). Некроз миокарда вызывали введением адреналина (0,5 мг/кг внутримышечно). Определяли интенсивность брадикардии при внутривенном введении ацетилхолина и электрической стимуляции n. vagus. Животных поделили на 4 группы: 1 - крысы, которые находились в условиях светового баланса (день/ночь); 2 - крысы, которые 10 дней находились в условиях световой депривации; 3 - крысы, которые 10 дней находились в условиях перманентного освещения; 4 - крысы, которые 10 дней находились в условиях перманентного освещения, но за 1 час до моделирования некроза получали мелатонин (5 мг/кг внутрибрюшинно).

Результаты. При развитии некроза миокарда на фоне световой депривации реакция сердца крыс на холинергическую стимуляцию увеличивалась: у самок - за счет увеличения чувствительности холинорецепторов и освобождения большего количества ацетилхолина из $\mathrm{n}$. vagus, а у самцов - только за счет увеличения чувствительности холинорецепторов. Развитие некроза миокарда в условиях перманентного освещения характеризовалось более существенной, чем при световом балансе, чувствительностью холинергических структур сердца к функциональным влияниям, особенно у самок.

Использование мелатонина способствовало тому, что при развитии некроза миокарда реакция холинергических структур сердца приближалась к показателям, зарегистрированным при световом балансе, хотя они оставались большими: у самок - за счет освобождения большего количества ацетилхолина из окончаний $\mathrm{n}$. vagus, а у самцов сочеталась $\mathrm{c}$ большей чувствительностью холинорецепторов.

Выводы. Развитие некроза миокарда на фоне светового десинхроноза (световая депривация или перманентное освещение) вызывает усиление реакции сердца крыс на холинергическую стимуляцию. Более существенными такие эффекты зарегистрированы в условиях перманентного освещения, особенно у самок. Использование мелатонина при моделировании некроза миокарда на фоне перманентного освещения способствует приближению (но не восстановлению) параметров, которые отображают чувствительность сердца к холинергической стимуляции в условиях светового баланса. Реакция сердца на холинергическую стимуляцию остается более существенной, особенно у самцов.

The prevalence of cardiovascular diseases in the list of high mortality causes is the main characteristic nowadays [1-3]. Stress takes the lead among the risk factors for coronary heart disease and myocardial infarction. Pineal gland dysfunction and abnormal circadian rhythm are worthy of being noted among the causes of stress [4]. Light desynchronosis occurs in shiftwork, jetlag and prolonged computer work. All above mentioned causes a significant exertion of stress adaptation mechanisms, their rapid exertion and cardiovascular system dysfunction in impaired light regime $[5,6]$.

Effective body adaptation to stress is possible due to the pineal gland hormone melatonin which is synthesized mainly during nighttime sleep. There is a good deal of evidence that melatonin reduces the effects of stress. It has been shown that melatonin desensitizes adrenergic receptors, reduces free radical oxidation due to antioxidant properties and ability to stabilize mitochondrial membranes, and enhances the realization of cholinergic effects at the central and peripheral levels, providing cardioprotection against stress, hypercatecholaminemia, ischemia/hypoxia [7-11].

It is also known that the incidence of cardiovascular pathology in light desynchronosis depends on the sex and occurs more frequently in men [12]. All these facts indicate the relevance of research studies aimed at analyzing the effect of light balance disorders on cardiovascular diseases development and sex-specific aspects of this issue. This will foster the development of not only cardiology, but also gender medicine.

\section{Aim}

The aim was to identify sex differences of the cardiac response to cholinergic stimuli in the development of myocardial necrosis and light desynchronosis.

\section{Materials and methods}

Experiments were conducted in 144 albino rats $(72$ males, 72 females) weighing 220-290 g, which were on a standard ration in vivarium conditions. Animals were divided into 4 groups: 1 - rats that were in a light balance (day/ night); 2 - rats exposed to light deprivation for 10 days; 3 - rats exposed to permanent lighting for 10 days; 4 - animals exposed to permanent lighting for 10 days and injected with melatonin (a single dose of $5 \mathrm{mg} / \mathrm{kg}$ ) intraperitoneally 1 hour before the myocardial necrosis (MN) modeling [7].

Light balance model: the animals were housed on day/night cycles for 10 days; cycle "Day" consisted of a 12-hour (from 7.00 to 19.00) 500 lux light, cycle "Night" lasted 12 hours (from 19.00 to 7.00 ) at 0.5-1.0 lux light. Model of light deprivation: animals were left in 0.51.0 lux light for 10 days. Permanent lighting model: animals were exposed to 500 lux light for 10 days. On the $11^{\text {th }}$ day, adrenaline-induced myocardial necrosis was modeled by adrenaline intramuscular injection $(0.5 \mathrm{mg} / \mathrm{kg})$.

The basic studies were performed 1 and 24 hours after injection, including standard lead II ECG registration using the Cardiolab-SE computer complex (Kharkiv,
Ключевые слова: некроз миокарда, световой Аесинхроноз, чувствительность холинорецепторов, n. vagus, пол.

Патология. 2020 T. 17, № 2(49). C. $142-148$ 
Table 1. Indicators of the rat heart response to cholinergic stimulation in the development of myocardial necrosis in light balance, $\mathrm{M} \pm \mathrm{m}$

\begin{tabular}{l|l|l|l|l} 
Indices & Sex & Control, $\mathbf{n = 6}$ & MN 1 hour, $\mathbf{n = 6}$ & MN 24 hours, $\mathbf{n = 6}$ \\
\hline $\mathrm{BI}_{\mathrm{vn}}$ & $\hat{0}$ & $6.85 \pm 0.31^{2}$ & $6.89 \pm 0.23^{2}$ & $7.49 \pm 0.35$ \\
& + & $8.25 \pm 0.45^{2}$ & $8.90 \pm 0.36^{2}$ & $6.68 \pm 0.40^{1}$ \\
$\mathrm{BI}_{\mathrm{ACh}}$ & 0 & $3.94 \pm 0.35$ & $3.88 \pm 0.30$ & $3.96 \pm 0.26$ \\
& + & $3.94 \pm 0.42$ & $3.52 \pm 0.38$ & $4.64 \pm 0.38$ \\
$\mathrm{BD}_{\mathrm{ACh}}(\mathrm{sec})$ & 0 & $18.8 \pm 1.0^{2}$ & $16.4 \pm 1.3$ & $17.9 \pm 1.2$ \\
& + & $25.7 \pm 0.9^{2}$ & $16.3 \pm 0.7^{1}$ & $17.8 \pm 0.8^{1}$ \\
\hline
\end{tabular}

1: significance of the differences in comparison with the control, $\mathrm{P}<0.05$; ${ }^{2}$ : significance of the differences between sexes, $\mathrm{P}<0.05$.

Table 2. Indicators of the rat heart response to cholinergic stimulation during the development of myocardial necrosis in light deprivation, $\mathrm{M} \pm \mathrm{m}$

\begin{tabular}{|c|c|c|c|c|}
\hline Indices & Sex & Control, $n=6$ & MN 1 hour, $n=6$ & MN 24 hours, $n=6$ \\
\hline \multirow[t]{2}{*}{$\mathrm{BI}_{\mathrm{vn}}$} & $\delta$ & $6.87 \pm 0.21^{3}$ & $6,08 \pm 0.29^{3}$ & $6.94 \pm 0.24^{3}$ \\
\hline & o & $12.03 \pm 0.30^{2,3}$ & $10.49 \pm 0.37^{1,2,3}$ & $8.20 \pm 0.22^{1,2,3}$ \\
\hline \multirow[t]{2}{*}{$\mathrm{BI}_{\mathrm{ACh}}$} & $\hat{o}$ & $8.21 \pm 0.33^{2}$ & $5.82 \pm 0.27^{1,2}$ & $6.01 \pm 0.35^{1,2}$ \\
\hline & q & $7.88 \pm 0.38^{2}$ & $6.19 \pm 0.21^{1,2}$ & $5.16 \pm 0.25^{1}$ \\
\hline \multirow[t]{2}{*}{$\mathrm{BD}_{\mathrm{ACh}}(\mathrm{sec})$} & $\hat{\sigma}$ & $12.9 \pm 0.7^{2,3}$ & $14.4 \pm 1.3^{3}$ & $13.5 \pm 1.2^{3}$ \\
\hline & q & $24.6 \pm 1.7^{3}$ & $20.7 \pm 1.3^{2,3}$ & $20.2 \pm 1.1^{2,3}$ \\
\hline
\end{tabular}

1: significance of the differences in comparison with the control, $\mathrm{P}<0.05 ;{ }^{2}$ : significance of the differences in comparison with group $1, \mathrm{P}<0.05 ;{ }^{3}$ : significance of the differences between sexes, $\mathrm{P}<0.05$.
The experiments on heart response to electrical stimulation were carried out in anesthetized animals (thiopental sodium $40 \mathrm{mg} / \mathrm{kg}$ of animal body weight, intraperitoneally) and followed the National "General Ethical Principles of Animal Experiments" (Ukraine, 2001) in accordance with the 2010/63EU Directive of the European Parliament and of the Council of September 22, 2010 on the protection of animals used for scientific purposes [13]. The experiments were conducted on the basis of the Central Research Laboratory (CRL) of the Ternopil National Medical University. All devices used for study were certified and had undergone annual metrological control (certificate of technical competence No. 001/18 dated September 26, 2018, valid until September 26, 2023).

Statistical processing was performed using a table processor Microsoft Excel 2016 (Microsoft Corp., USA). For all the parameters, the arithmetic mean (M), its dispersion and mean error $(\mathrm{m})$ were calculated. To determine the significance of differences between the study results in the experimental groups of animals, the Student's coefficient (t) was calculated, after that, the significance of the differences between the samples ( $p$ ) and the confidence interval of the mean according to the Student's t-distribution tables were calculated. $\mathrm{P}_{\mathrm{St}}$ values $<0.05$ were considered statistically significant (program BioStat, AnalystSoft Inc., version 6) [14].

Ukraine). The cardiac response to exogenous acetylcholine (ACh) injected into the jugular vein $(50 \mathrm{mg} / \mathrm{kg}$ to a maximum of $0.1 \mathrm{ml} / 100 \mathrm{~g}$ of animal body weight) was evaluated by bradycardia intensity $\left(\mathrm{BI}_{\mathrm{ACh}}\right)$ and bradycardia duration $\left(\mathrm{BD}_{\mathrm{ACh}}\right)$. $\mathrm{BI}_{\mathrm{ACh}}$ was calculated by the formula:

$$
B I_{\mathrm{ACh}}=(R-R) \max /(R-R) m
$$

The value of $(R-R) m$ was equal to the arithmetic mean of the (R-R) intervals recorded on the ECG before the ACh injection; the value of $(R-R)$ max was equal to the maximum $(R-R)$ value after the ACh injection.

This indicator reflects the sensitivity of cholinoreceptors in the sinus node. $\mathrm{BD}_{\mathrm{ACh}}$ is the period between the onset and termination of a negative chronotropic effect (expressed in seconds), reflecting the duration of functional desensitization of cholinoreceptors. Heart response to electrical stimulation of the right peripheral segment of vagus nerve was estimated by bradycardia intensity $\left(\mathrm{BI}_{\mathrm{vn}}\right)$.

Electrical stimulation was performed using an ELS-2 (electrical laboratory stimulator). Operation parameters of the device: electrical impulse duration $-1 \mathrm{~ms}$, impulse delay $-1 \mathrm{~ms}$, impulse amplitude $-2 \mathrm{~V}$, impulse frequency $-50 \mathrm{~Hz}$. The peripheral segment of the nerve was isolated at the level of the lower cartilage of the larynx and placed on copper electrodes (a pole separation was $4 \mathrm{~mm}$ ). The nerve was stimulated for 60 seconds. $\mathrm{BI}_{\mathrm{vn}}$ was calculated by the formula (1), but the value of $(R-R)$ $m$ was equal to the arithmetic mean of the $(R-R)$ intervals recorded on the ECG before electrical stimulation of vagus nerve; $(R-R)$ max - maximum value $(\mathrm{R}-\mathrm{R})$ during vagus nerve stimulation.

This parameter reflects ACh content in the presynaptic vagus nerve terminals. Experiments studying the heart response to cholinergic stimulation were carried out in anesthetized animals (thiopental sodium, $40 \mathrm{mg} / \mathrm{kg}$, intraperitoneally).

\section{Results}

Analysis of the animal data obtained in group 1 showed that male $\mathrm{BI}_{\mathrm{vn}}$ did not change in $\mathrm{MN}$ development and light balance (Table 1).

Female $\mathrm{BI}_{\mathrm{vn}}$ decreased by $24 \%$ within $24 \mathrm{~h}$ of $\mathrm{MN}$. Neither male nor female $\mathrm{BI}_{\mathrm{ACh}}$ changed in the development of $\mathrm{MN} . \mathrm{BD}_{\mathrm{ACh}}$ was changed only in females, it represented a $58 \%$ decrease (within $1 \mathrm{~h}$ of $\mathrm{MN}$ ) and $44 \%$ (within $24 \mathrm{~h}$ of MN) in comparison to the control. Sex-specific analysis showed that the value of $\mathrm{BI}_{\mathrm{vn}}$ was significantly lower in the control and within $1 \mathrm{~h}$ of $\mathrm{MN}$ in males than in females, by $20 \%$ and $29 \%$, respectively, but there was no significant difference between males and females within $24 \mathrm{~h}$ of MN. Males and females of group 1 did not differ in $\mathrm{BI}_{\mathrm{ACh}}$. $\mathrm{BD}_{\mathrm{ACh}}$ in males was less than in females only in the control (by $37 \%$ ), but not in MN.

An analysis of the indicators in animal group 2 showed that the development of $\mathrm{MN}$ in light deprivation in males did not cause a significant change in $\mathrm{BI}_{\mathrm{vn}}$ (Table 2).

$\mathrm{BI}_{\mathrm{ACh}}$ was decreased by $41 \%$ (within $1 \mathrm{~h}$ of $\mathrm{MN}$ ) and $37 \%$ (within $24 \mathrm{~h}$ of $\mathrm{MN}$ ). The indicator of $\mathrm{BD}_{\mathrm{ACh}}$ was not changed. Female $\mathrm{BI}_{\mathrm{vn}}$ was $15 \%$ and $48 \%$ decreased within $1 \mathrm{~h}$ and $24 \mathrm{~h}$ of $\mathrm{MN}$, respectively, as compared to the control. Female $\mathrm{BI}_{\mathrm{ACh}}$ of group 2 was $27 \%$ and $53 \%$ decreased within $1 \mathrm{~h}$ and $24 \mathrm{~h}$ of $\mathrm{MN}$, respectively. There were no significant changes in $\mathrm{BD}_{\mathrm{ACh}}$. Sex-specific analysis of group 1 indicators showed that male $\mathrm{BI}_{\mathrm{vn}}$ was lower than that in females, in particular, by $75 \%$ in the control, by $73 \%$ (within $1 \mathrm{~h}$ of $\mathrm{MN}$ ) and by $17 \%$ (within $24 \mathrm{~h}$ of $\mathrm{MN}$ ). A reduction in the difference was due to this indicator changes only in females. There was no sex difference in $\mathrm{BI}_{\mathrm{ACh}}$. Male $\mathrm{BD}_{\mathrm{ACh}}$ was less than that in females of group 2, by $91 \%$ - in the control, by $44 \%$ (within $1 \mathrm{~h}$ of $\mathrm{MN}$ ), by $50 \%$ (within $24 \mathrm{~h}$ of $\mathrm{MN}$ ). 
A comparative analysis of the light deprivation influence on the studied parameters between the indicators of group 1 and group 2 showed the following. There was no difference in the male cohort with regard to $\mathrm{BI}_{\mathrm{vn}}$. $\mathrm{BI}_{\mathrm{ACn}}$ in males of group 2 was higher than that in animal group 1 , 2.1 times in the control, 1.5 times within $1 \mathrm{~h}$ of $\mathrm{MN}, 1.5$ times within $24 \mathrm{~h}$ of $\mathrm{MN} \mathrm{BD}_{\mathrm{ACh}}$ was $46 \%(\mathrm{P}<0.05)$ less only in the control and did not differ in MN development between male indicators of both groups. In females of group 2, $\mathrm{BI}_{\mathrm{vn}}$ was $46 \%$ higher in the controls, $18 \%$ - within $1 \mathrm{~h}$ of $\mathrm{MN}$, $22 \%$ - within $24 \mathrm{~h}$ of $\mathrm{MN} ; \mathrm{BI}_{\mathrm{ACh}}$ was 2.0 times higher in the controls, 1.8 times - within $1 \mathrm{~h}$ of $\mathrm{MN} ; \mathrm{BD}_{\mathrm{ACh}}$ was higher by $27 \%$ within $1 \mathrm{~h}$ of MN and by $13 \%$ within $24 \mathrm{~h}$ of $\mathrm{MN}$.

The results of analysis between indicators in animal group 3 revealed (Table 3) that male $\mathrm{BI}_{\mathrm{vn}}$ was 1.9 times and 5.2 times decreased within $1 \mathrm{~h}$ and $24 \mathrm{~h}$ of MN, respectively; $\mathrm{BI}_{\mathrm{ACh}}$ was 1.5 times and 2.6 times increased within $1 \mathrm{~h}$ and $24 \mathrm{~h}$ of $\mathrm{MN}$, respectively; $\mathrm{BD}_{\mathrm{ACh}}$ was also 1.5 times and 2.0 times increased within $1 \mathrm{~h}$ and $24 \mathrm{~h}$ of $\mathrm{MN}$, respectively.

In females, $\mathrm{BI}_{\mathrm{vn}}$ was 1.7 times increased within $1 \mathrm{~h}$ of $\mathrm{MN}$, but it was 12.1 times decreased within $24 \mathrm{~h}$ of $\mathrm{MN} ; \mathrm{BI}_{\mathrm{ACh}}$ was 10.3 times decreased within $1 \mathrm{~h}$ of $\mathrm{MN}$, and it was 1.8 times less than in the control within $24 \mathrm{~h}$; $\mathrm{BD}_{\mathrm{ACh}}$ was also less than in the control, in particular, by 4.2 times and 1.5 times within $1 \mathrm{~h}$ and $24 \mathrm{~h}$ of $\mathrm{MN}$, respectively. Sex-specific analysis of group 2 indicators showed that $\mathrm{BI}_{\mathrm{vn}}$ in males was less than in females only in the control and within $1 \mathrm{~h}$ of MN, by 2.4 times and 7.6 times, respectively. Male $\mathrm{BI}_{\mathrm{ACh}}$ in the control were 8.0 times less than in females, 2.0 times within $1 \mathrm{~h}$ of $\mathrm{MN}$ and 1.7 times within $24 \mathrm{~h}$ of $\mathrm{MN} \mathrm{BD}_{\mathrm{ACh}}$ in males was 3.6 times less than in the control females, it was 1.8 times higher within $1 \mathrm{~h}$ of $\mathrm{MN}$ and $17 \%$ less within $24 \mathrm{~h}$ of MN as compared to females.

Comparison of indicators between animal group 3 and group 1 showed that male $\mathrm{BI}$ in group 3 was higher than that in group 1, in particular, by 6.2 times in the controls and by 3.2 times within $1 \mathrm{~h}$ of $\mathrm{MN} \mathrm{BI}_{\mathrm{ACh}}$ was decreased in the control and within $1 \mathrm{~h}$ of MN by 2.1 times and $32 \%$, respectively, and $28 \%$ increased within $24 \mathrm{~h}$ of $M N$. $\mathrm{BD}_{\mathrm{ACh}}$ was 1.9 times less than in the control. Female $\mathrm{BI}_{v n}$ in group 3 was higher than that in group 1, in particular, by 12.2 times in the control, by 18.7 times within $1 \mathrm{~h}$ of $\mathrm{MN}$, by $24 \%$ within $24 \mathrm{~h}$ of $\mathrm{MN}$. Control $\mathrm{BI}_{\mathrm{ACh}}$ was 3.9 times higher than the compared value, $\mathrm{BI}_{\mathrm{ACh}}$ was 2.4 times lower within $1 \mathrm{~h}$ of $\mathrm{MN}$ and 1.8 times higher within $24 \mathrm{~h}$. $\mathrm{BD}_{\mathrm{ACh}}$ was $39 \%$ higher in the control, 1.9 times lower within $1 \mathrm{~h}$ of $\mathrm{MN}$ and $30 \%$ higher within $24 \mathrm{~h}$ of $\mathrm{MN}$.

Analysis of indicators in the animal group 4 showed (Table 4) that male $\mathrm{BI}_{\mathrm{vn}}$ in $\mathrm{MN}$ was increased, in particular, by 1.5 times within $1 \mathrm{~h}$ of $\mathrm{MN}$ and by 3.0 times within $24 \mathrm{~h}$ of $\mathrm{MN}$.

$\mathrm{BI}_{\mathrm{ACh}}$ was 2.3 times increased within $1 \mathrm{~h}$ of $\mathrm{MN}$, but this indicator did not differ from the control within $24 \mathrm{~h}$ of $\mathrm{MN} . \mathrm{BD}_{\mathrm{ACh}}$ in this model was not changed. Female $\mathrm{BI}_{\mathrm{vn}}$ was $21 \%$ decreased within $1 \mathrm{~h}$ of $\mathrm{MN}$, and $28 \%$ higher within $24 \mathrm{~h}$ of $\mathrm{MN}$ than in the control. $\mathrm{BI}_{\mathrm{ACh}}$ was $37 \%$ and 3.3 times decreased within $1 \mathrm{~h}$ and $24 \mathrm{~h}$ of $\mathrm{MN}$. $\mathrm{BD}_{\mathrm{ACh}}$ was not changed. Sex-specific analysis of group 4 indicators revealed that control $\mathrm{BI}$ wn 1.8 times less in males than that in females, there was no sex difference
Table 3. Indicators of the rat heart response to cholinergic stimulation in the development of myocardial necrosis in permanent lighting, $\mathrm{M} \pm \mathrm{m}$

\begin{tabular}{|c|c|c|c|c|}
\hline Indices & Sex & Control, $n=6$ & MN 1 hour, $n=6$ & MN 24 hours, $n=6$ \\
\hline \multirow[t]{2}{*}{$\mathrm{Bl}_{\mathrm{vn}}$} & $\hat{0}$ & $42.18 \pm 2.27^{3,2}$ & $21.86 \pm 1.60^{1,3,2}$ & $8,11 \pm 0,30^{1}$ \\
\hline & ㅇ & $100.72 \pm 4.52^{3,2}$ & $166.36 \pm 5.76^{1,3,2}$ & $8,31 \pm 0,33^{1,2}$ \\
\hline \multirow{2}{*}{$\mathrm{BI}_{\mathrm{ACh}}$} & $\hat{\alpha}$ & $1.91 \pm 0.08^{2,3}$ & $2.95 \pm 0.17^{1,2,3}$ & $5.05 \pm 0.15^{1,2,3}$ \\
\hline & q & $15.30 \pm 0.45^{2,3}$ & $1.48 \pm 0.10^{1,2,3}$ & $8.36 \pm 0.35^{1,2,3}$ \\
\hline \multirow{2}{*}{$\mathrm{BD}_{\mathrm{ACh}}(\mathrm{sec})$} & $\hat{0}$ & $9.9 \pm 0.5^{2,3}$ & $15.0 \pm 1.7^{1,3}$ & $19.9 \pm 1.2^{1,3}$ \\
\hline & 우 & $35.8 \pm 1.8^{2,3}$ & $8.5 \pm 0.4^{1,2,3}$ & $23.2 \pm 1.7^{1,2,3}$ \\
\hline
\end{tabular}

1: significance of the differences in comparison with the control, $P<0.05 ;{ }^{2}$ : significance of the differences in comparison with group $1, \mathrm{P}<0.05 ;^{3}$ : significance of the differences between sexes, $\mathrm{P}<0.05$

Table 4. Indicators of the rat heart response to cholinergic stimulation in the development of myocardial necrosis and permanent lighting with melatonin correction, $\mathrm{M} \pm \mathrm{m}$

\begin{tabular}{|c|c|c|c|c|}
\hline Indices & $\operatorname{Sex}$ & Control, $n=6$ & MN 1 hour, $n=6$ & MN 24 hours, $n=6$ \\
\hline \multirow{2}{*}{$\mathrm{BI}_{\mathrm{vn}}$} & $\hat{0}$ & $5.99 \pm 0.26^{3}$ & $9.07 \pm 0.33^{1,2}$ & $18.23 \pm 0.91^{1,3,2}$ \\
\hline & q & $10.69 \pm 0.39^{3,2}$ & $8.82 \pm 0.33^{1}$ & $13.70 \pm 0.62^{1,3,2}$ \\
\hline \multirow[t]{2}{*}{$\mathrm{BI}_{\mathrm{ACh}}$} & $\hat{0}$ & $5.10 \pm 0.29^{2,3}$ & $11.79 \pm 0.49^{1,2,3}$ & $5.00 \pm 0.27^{3}$ \\
\hline & 우 & $6.80 \pm 0.35^{3,2}$ & $4.95 \pm 0.28^{1,2,3}$ & $2.07 \pm 0.11^{1,2,3}$ \\
\hline \multirow[t]{2}{*}{$\mathrm{BD}_{\mathrm{ACh}}(\mathrm{sec})$} & $\hat{0}$ & $17.4 \pm 2.3$ & $14.7 \pm 2.1$ & $14.2 \pm 2.3$ \\
\hline & q & $21.2 \pm 1.7$ & $18.3 \pm 1.6$ & $21.3 \pm 3.0$ \\
\hline
\end{tabular}

1: significance of the differences in comparison with the control, $\mathrm{P}<0.05 ;{ }^{2}$ : significance of the differences in comparison with group $1, \mathrm{P}<0.05 ;{ }^{3}$ : significance of the differences between sexes, $P<0.05$

within $1 \mathrm{~h}$ of $\mathrm{MN}$, and this indicator was $33 \%$ higher in males than that in females within $24 \mathrm{~h}$ of $\mathrm{MN}$. Male $\mathrm{BI}_{\mathrm{ACh}}$ in similar conditions was $33 \%$ less in the control than that in females, but it was 2.4 times and 1.9 times higher within $1 \mathrm{~h}$ and $24 \mathrm{~h}$ of $\mathrm{MN}$, respectively. $\mathrm{BD}_{\mathrm{ACh}}$ did differ significantly between males and females.

Comparison of the animal indices between group 4 and 1 indicated no difference in control $\mathrm{BI}$, between males of group 4 and group 1. However, in MN development, male $\mathrm{BI}_{\mathrm{vn}}$ value in group 4 was significantly higher, by $32 \%$ and by 2.4 times within $1 \mathrm{~h}$ and $24 \mathrm{~h}$, respectively. A similar comparison demonstrated that $\mathrm{BI}_{\mathrm{ACh}}$ was $29 \%$ and 3.0 times higher in the control and within $1 \mathrm{~h}$ of $\mathrm{MN}$ development, respectively. $\mathrm{BD}_{\mathrm{ACh}}$ did not differ in the groups compared. In females of group 4, $\mathrm{BI}_{\mathrm{vn}}$ was $30 \%$ higher in the control, there was no significant difference within $1 \mathrm{~h}$ of $\mathrm{MN}$, and it was 2.1 times higher within $24 \mathrm{~h}$ of $\mathrm{MN}$ than the value compared. Female $\mathrm{BI}_{\mathrm{ACh}}$ in group 4 was $73 \%$ and $41 \%$ higher in the control and within $1 \mathrm{~h}$ of $\mathrm{MN}$, respectively, than in group 1 , and it was 2.2 times lower within $24 \mathrm{~h}$ of $\mathrm{MN}$. The indices of $\mathrm{BD}_{\mathrm{ACh}}$ did not differ between comparison groups.

\section{Discussion}

The results obtained in our studies demonstrated a light desynchronosis influence on the cholinergic heart structures functional state regardless of the variant of lighting regime violation (light deprivation or permanent lighting). A 10-day stay in the dark caused a significant increase in the sensitivity of cholinoreceptors in the sinoatrial node, which was confirmed by an increase in $\mathrm{BI}_{\mathrm{ACh}}$ after $\mathrm{ACh}$ injection into the jugular vein. In males, this effect was impeded by a shortening of the functional desensitization period (decrease in $\mathrm{BD}_{\mathrm{ACh}}$ ). In contrast, the increase in 
$\mathrm{BD}_{\mathrm{ACh}}$ indicated a longer desensitization and a higher baseline functional activity of cholinoreceptors in the sinoatrial node in females. In this context, the development of MN was characterized by the greater sensitivity of the heart to exogenous ACh than in the light balance. It was confirmed by the greater values of $\mathrm{BI}_{\mathrm{ACh}}$. Such changes were more significant in females. Simultaneous increase in $\mathrm{BD}_{\mathrm{ACh}}$ was indicative of the increase in time of functional desensitization, which also allows for longer duration of bradycardia and depends on the rate of ACh release from the synaptic cleft depending on an acetylcholinesterase influence.

The study of the animal heart response to the electrical stimulation of vagus nerve in MN development and light balance showed the pattern which was observed by other authors in the studies using adrenaline to induce MN [7]. Such data consistency validated the correctness of experimental conditions and optimal dose of adrenaline. Cardiotoxic effect of adrenaline has been confirmed biochemically [15]. Interestingly, 10-day light deprivation did not affect the rate of $\mathrm{BI}_{\mathrm{vn}}$ in males, but contributed to its increase in females. The last fact was predicted by us, given that the development of $\mathrm{MN}$ causes more significant changes in the female activity of the heart cholinergic structures than in male $[7,16,17]$. The absence of changes in male $\mathrm{BI}_{\mathrm{vn}}$, which value reflects the $\mathrm{ACh}$ content in the presynaptic vagus nerve terminals, may indicate either a lower melatonin mediation of the resynthesis and accumulation of a neurotransmitter in the presynaptic compartment, or its smaller amount in the body. It is known that in vertebrates, the hormone is mainly synthesized in darkness [18], therefore we rather tend to think that melatonin synthesis was less in males than in females as a result of 10-day complete darkness.

The permanent lighting model yielded interesting and unpredictable results. The desynchronosis modeled in this way resulted in dramatically increased value of $\mathrm{IB}_{\mathrm{vn}}$, in particular by 6.2 times in males and by 12.2 times in females, indicating a significant accumulation of ACh in the presynaptic compartment. This fact can be explained in view of the autonomic nervous system role in the chronotropic heart function maintenance. It is known that the absence of darkness, which is the main condition for the realization of the pineal gland circadian activity, is a severe stress, a cause of sleep onset insomnia [5], a factor of coronary heart disease and arterial hypertension progression due to a high sympathoadrenal activity [11]. In this case, the phenomenon of "enhanced antagonism" of the vagus nerve may be triggered in conditions of delayed inactivation of norepinephrine. That is, the higher the adrenergic activity, the more significant is the heart response to vagus nerve stimulation, and this effect is attenuated largely by beta-adrenoceptors blockade [20]. Interestingly, in our experiment at the same time, female sensitivity of cholinoreceptors $\left(\mathrm{BI}_{\mathrm{ACh}}\right)$ and duration of functional desensitization were increased. This idea is evidenced by the fact that, in our study, the female value of $\mathrm{BI}_{\mathrm{vn}}$ continued to increase within $1 \mathrm{~h}$ of $\mathrm{MN}$, which is a period of hyperadrenalinemia, despite the significantly decreased cholinoreceptor sensitivity $\left(\mathrm{BI}_{\mathrm{ACh}}\right)$ and the significantly reduced time of functional desensitization. It is unlikely that accumulation of a large amount of ACh in the vagus nerve presynaptic department alone could explain such effect in the conditions of 10-day permanent lightning, since a long-term absence of darkness and normal sleep would have depleted the depot of ACh to impede constantly high adrenergic activity. In this case, the role of intestinal natriuretic peptide may be considered as a non-cholinergic component capable of mediating the effects of vagus nerve [20], or nitrogen monoxide appears to be involved, the role of which in cholinergic effects mediation is more significant in females [21]. There is evidence of greater involvement of nitrogen monoxide in mediating the heart cholinergic effects in females [22]. Unlike females, males presented the decrease in $\mathrm{BI}_{\mathrm{vn}}$ while cholinoreceptor sensitivity $\left(\mathrm{BI}_{\mathrm{ACh}}\right)$ and the time of functional desensitization $\left(B_{A C h}\right)$ increasing within $1 \mathrm{~h}$ of $\mathrm{MN}$ development in the permanent lightning, which could be the result of faster synergistic desensitization [20] and was evidenced by a continuation of this trend within $24 \mathrm{~h}$ of MN (worsening of damage signs) in animals of both sexes. Generally, males and females demonstrated opposite reactions in conditions of hyperadrenalinemia, which indirectly reflects not only different levels of melatonin deficiency, but also different patterns of cardiovascular system adaptation in pathological conditions.

Based on the data obtained, to confirm the pineal hormone deficiency in conditions of permanent lightning and for cardioprotection, exogenous melatonin was used in animal group 4. It is known that the maximum level of hormone in the mediobasal hypothalamus, striatum and neocortex occurs in an hour after its parenteral injection, and a sufficiently high level is maintained in blood plasma for 3-4 hours. The positive effect of melatonin has been established in the treatment of patients with myocardial infarction, after angioplasty to prevent reperfusion injury $[23,24]$. The results obtained have confirmed a melatonin deficiency in conditions of permanent lightning in animals as all the indicators reflecting the heart response to cholinergic stimulation differed from those in animal group 3. The comparison of absolute values showed a tendency to approximation (but not restoration) of all the cholinoreceptor state parameters characterizing the light balance. In our opinion, exogenous melatonin served as an anti-stress factor that reduced the adrenergic reactivity and effect of "enhanced antagonism" [19]. In the development of $\mathrm{MN}$, the dynamics of $\mathrm{BI}_{\mathrm{vn}}, \mathrm{BI}_{\mathrm{ACh}}$, and $\mathrm{BD}_{\mathrm{ACh}}$ were different from those in animal group 1 . That is, in our study, exogenous melatonin most likely displayed a regulatory function that is realized involving two mechanisms - cAMP and cGMP-PKG (protein kinase G) - dependent pathways [8]. The final effect was indicative of not only the more balanced heart response to cholinergic stimuli, but also the decrease in adrenoreactivity, which was confirmed by the more significant dynamics of indicators in males of group 4 as well as data from previous studies, which had demonstrated the higher myocardial irritability related to the damaging effect of adrenaline in males [15].

\section{Conclusions}

1. 10-day light deprivation increases the response of rat heart to cholinergic effects maintaining such state 
in conditions of adrenaline-induced myocardial necrosis, and is realized by increased cholinoreceptor sensitivity and acetylcholine accumulation in the vagus nerve presynaptic department in females and only by increased cholinoreceptor sensitivity in males.

2. 10-day permanent lightning (500 lux) causes the substantial increase in the heart response to cholinergic stimulation. The more intensive response of the female heart to vagus nerve stimulation, compared with male, is caused by the increased release of acetylcholine from the presynaptic compartment with simultaneous increase in the cholinoreceptor sensitivity, in contrast to decreased male cholinoreceptor sensitivity. The development of adrenaline-induced myocardial necrosis in females is characterized by greater sensitivity of the heart cholinergic structures to functional influences compared to light balance conditions and male response.

3. Melatonin $(5 \mathrm{mg} / \mathrm{kg})$ reduces the heart response to cholinergic stimulation in conditions of permanent lightning, results in the approximation (but not restoration) of the intensity of the heart response to cholinergic stimuli, which is characteristic of light balance conditions. At the same time, the sensitivity of cholinoreceptors is greater than in conditions of light balance, especially in females. The development of adrenaline-induced myocardial necrosis in this case is characterized by greater heart response to stimulation of vagus nerve than in light balance regardless of sex, and is combined with greater cholinoreceptor sensitivity in males.

The prospect of further research includes detecting the sex differences in melatonin metabolism (endogenous and exogenous) in adrenaline-induced myocardial necrosis and light desynchronosis, which is relevant to the gender pharmacology development.

\section{Funding}

The scientific research was carried out as part of the complex research work of the Educational and Scientific Institute of Modeling and Analysis of pathological processes of Ivan Horbachevsky Ternopil National Medical University of the Ministry of Health of Ukraine on the theme: "Systemic and organ disorders in the influence of extraordinary factors on the organism, mechanisms of their development and pathogenetic correction" (state registration number 016U003390).

Conflicts of interest: authors have no conflict of interest to declare. Конфмікт інтересів: віАсутній.

НаАійшла Ао редакції / Received: 03.04.2020

Після Аоопрацювання / Revised: 23.04.2020

Прийнято АО Аруку / Accepted: 11.05.2020

Information about authors:

Khara M. R., MD, PhD, DSc, Professor of the Department of Pathological Physiology, Ivan Horbachevsky Ternopil National Medical University of the Ministry of Health of Ukraine. ORCID ID: 0000-0002-6028-9876

Bezkorovaina H. O., MD, Postgraduate Student

of the Department of Pathological Physiology, Ivan Horbachevsky

Ternopil National Medical University of the Ministry of Health of Ukraine.

ORCID ID: 0000-0003-2722-7013
Klishch I. M., MD, PhD, DSc, Vice-rector for Scientific Work, Professor of the Department of Functional and Laboratory Diagnostics, Ivan Horbachevsky Ternopil National Medical University of the Ministry of Health of Ukraine.

ORCID ID: 0000-0001-6226-4296

Pelykh V. Ye. MD, PhD, Associate Professor of the Department of Pathological Physiology, Ivan Horbachevsky Ternopil National Medical University of the Ministry of Health of Ukraine. ORCID ID: 0000-0003-3468-858X

\section{Відомості про авторів:}

Хара М. Р., А-р меА. наук, професор каф. патологічної фізіології, Тернопільський національний медичний університет імені І. Я. Горбачевського М0З України.

Безкоровайна Г. О., лікар, зАобувач наукового ступеня, каф. патологічної фізіології, Тернопільський національний медичний університет імені І. Я. Горбачевського МОЗ України.

Кліщ I. М., А-р біол. наук, проректор з наукової роботи, професор каф. функціональної і лабораторної Аіагностики, Тернопільський національний медичний університет імені І. Я. Горбачевського МОЗ України.

Пелих В. Є., канА. меА. наук, доцент каф. патологічної фізіології, Тернопільський національний меАичний університет імені І. Я. Горбачевського МОЗ України.

\section{Сведения об авторах:}

Хара М. Р., А-р меА. наук, профессор каф. патологической физиологии, Тернопольский национальный медицинский университет имени И. Я. Горбачевского МЗ Украины. Безкоровайная Г. А., врач, соискатель ученой степени, каф. патологической физиологии, Тернопольский национальный меАицинский университет имени И. Я. Горбачевского МЗ Украины.

Клищ И. Н., А-р биол. наук, проректор по научной работе, профессор каф. функциональной и лабораторной Аиагностики, Тернопольский национальный медицинский университет имени И. Я. Горбачевского МЗ Украины.

Пелых В. Е., канА. меА. наук, Аоцент каф. патологической физиологии, Тернопольский национальный медицинский университет имени И. Я. Горбачевского МЗ Украины.

\section{References}

[1] Nicholas, M., Townsend, N., Scarborough, P., \& Rayner, M. (2015). Corrigendum to: cardiovascular disease in Europe 2014: epidemiological update. European heart journal, 36(13), 794. https://doi.org/10.1093/ eurheart/ehu489

[2] Roth, G. A., Forouzanfar, M. H., Moran, A. E., Barber, R., Nguyen, G., Feigin, V. L., Naghavi, M., Mensah, G. A., \& Murray, C. J. (2015). Demographic and epidemiologic drivers of global cardiovascular mortality. The New England journal of medicine, 372(14), 1333-1341. https://doi. org/10.1056/NEJMoa1406656

[3] EUGenMed Cardiovascular Clinical Study Group, Regitz-Zagrosek, V., Oertelt-Prigione, S., Prescott, E., Franconi, F., Gerdts, E., Foryst-Ludwig, A., Maas, A. H., Kautzky-Willer, A., Knappe-Wegner, D., Kintscher, U., Ladwig, K. H., Schenck-Gustafsson, K., \& Stangl, V. (2016). Gender in cardiovascular diseases: impact on clinical manifestations, management, and outcomes. European heart journal, 37(1), 24-34. https://doi.org/10.1093/eurhearti/ehv598

[4] Reitz, C. J., \& Martino, T. A. (2015). Disruption of Circadian Rhythms and Sleep on Critical IIIness and the Impact on Cardiovascular Events. Current Pharmaceutical Design, 21(24), 3505-3511. https://doi.org/10. 2174/1381612821666150706105926

[5] Fullagar, H., Skorski, S., Duffield, R., \& Meyer, T. (2016). The effect of an acute sleep hygiene strategy following a late-night soccer match on recovery of players. Chronobiology International, 33(5), 490-505. https://doi.org/10.3109/07420528.2016.1149190

[6] Gostyukhina, A. A., Zamoshchina, T. A., Zaitsev, K. V., Gutor, S. S. Zhukova, O. B., Svetlik, M. V., Abdulkina, N. G., \& Zaitsev, A. A. (2018). Adaptivnye reaktsii krys posle svetovykh desinkhronozov i fizicheskogo pereutomleniya [Adaptive reactions of rats after light desynchronosis and physical overwork]. Bulletin of Siberian Medicine, 17(3), 22-34. [in Russian]. https://doi.org/10.20538/1682-0363-2018-3-22-34

[7] Khara, M. R. \& Shkumbatyuk, O. V. (2014). Polovye otlichiya reaktsi miokardial'nykh kholinoretseptorov pri povrezhdenii serdtsa adrenalinom na fone melatonina [Gender Difference of Myocardial Cholinergic Receptors Sensitivity at Adrenalin Heart Damage on the Ground of Melatonin]. Visnyk problem biolohii i medytsyny, (4), 176-179. [in Russian]. 
[8] Yu, L. M., Di, W. C., Dong, X., Li, Z., Zhang, Y., Xue, X. D., Xu, Y. L., Zhang, J., Xiao, X., Han, J. S., Liu, Y., Yang, Y., \& Wang, H. S. (2018). Melatonin protects diabetic heart against ischemia-reperfusion injury, role of membrane receptor-dependent cGMP-PKG activation. Biochimica Et Biophysica Acta-Molecular Basis of Disease, 1864(2), 563-578. https://doi.org/10.1016/i.bbadis.2017.11.023

[9] Genade, S., Genis, A., Ytrehus, K., Huisamen, B., \& Lochner, A. (2008). Melatonin receptor-mediated protection against myocardial ischaemia/reperfusion injury: role of its anti-adrenergic actions. Journal of Pineal Research, 45(4), 449-458. https://doi.org/10.1111/j.1600079X.2008.00615.x

[10] Green, E. A., Black, B. K., Biaggioni, I., Paranjape, S. Y., Bagai, K., Shibao, C., Okoye, M. C., Dupont, W. D., Robertson, D., \& Raj, S. R. (2014). Melatonin Reduces Tachycardia in Postural Tachycardia Syndrome: A Randomized, Crossover Trial. Cardiovascular Therapeutics, 32(3), 105-112. https://doi.org/10.1111/1755-5922.12067

[11] Campos, L., Cipolla-Neto, J., \& Michelini, L. (2013). Melatonin modulates baroreflex control via area postrema. Brain And Behavior, 3(2), 171-177. https://doi.org/10.1002/brb3.123

[12] Pyle, W. G., \& Martino, T. A. (2018). Circadian rhythms influence cardiovascular disease differently in males and females: role of sex and gender. Current Opinion in Physiology, 5, 30-37. https://doi. org/10.1016/j.cophys.2018.05.003

[13] Verkhovna Rada of Ukraine. (2006, February 21). Pro zakhyst tvaryn vid zhorstokoho povodzhennia ; zakon Ukrainy vid 21.02.2006 No. 3447-IV [On the Protection of Animals from Brutal Treatment (No. 3447-IV)] https://zakon.rada.gov.ua/laws/show/3447-15?lang=en

[14] Zaitsev, V. M., Liflyandskii, V. G., \& Marinkin, V. I. (2006). Prikladnaya meditsinskaya statistika [Applied Medical Statistics]. St. Petersburg: Foliant. [in Russian].

[15] Bezkorovaina, H. O., Klishch, I. M., \& Khara, M. R. (2020). Statevi vidminnosti vilnoradykalnykh protsesiv u miokardi pry ushkodzhenni adrenalinom na tli svitlovoi depryvatsii [Gender difference of free-radical processes in the myocardium at adrenaline damage on the background of light deprivation]. Medical and Clinical Chemistry, (4), 13-19. [in Ukrainian]. https://doi.org/10.11603/mcch.2410-681X.2019.v.14.10821

[16] Khara, M. R., Kuziv, O. V., \& Pelykh, V. Ye. (2015). Vplyv systemy oksydu azotu na chutlyvist cholinoretseptoriv sertsia pry poshkodzhenni adrenalinom v tvaryn zalezhno vid stati ta aktyvnosti honad [Effect of Nitric Oxide on Cholinireceptors of Heatr of Animals at Damage by Adrenalin in Terms of Sex and Activity of the Gonads]. ScienseRise, 5(4), 122-128. [in Ukrainian]. https://doi.org/https://doi. org/10.15587/2313-8416.2015.43305

[17] Khara, M. R., \& Kuchyrka, L. I. (2014). Rol melatoninu u kholiroreaktyvnosti miokarda honadektomovanykh shchuriv pry poshkodzhenni adrenalinom [Role of melatonin in holyroreactivity infarction in rats honadektomy damage adrenaline]. Aktualnye problemy transportnoi mediciny, 2(2), 21-26. [in Ukrainian].

[18] ViviD, D., \& Bentley, G. E. (2018). Seasonal Reproduction in Vertebrates: Melatonin Synthesis, Binding, and Functionality Using Tinbergen's Four Questions. Molecules, 23(3), Article 652. https://doi. org/10.3390/molecules23030652

[19] Korkushko, O. V., \& Pishak, V. P. (2012). V. I. Vernadskyi i khronorytmichna orhanizatsiia biosfery [V. I. Vernadskiy and chronorhythmic organization of the biosphere]. Krovoobih ta hemostaz, (4), 5-11. [in Ukrainian].

[20] Malyarenko, Y. E., Malyarenko, T. N., Matyukhov, A. V., \& Govsha, Y. A. (2001). Vegetativnoe obespechenie khronotropnoi funktsii serdtsa [The autonomic providing of the heart chronotropic function]. Vestnik TGU, 6(2), 230-240. [in Russian].

[21] Chiglintsev, V. M. (2013). Vliyanie stimulyatsii bluzhdayushchikh nervov na pokazateli serdechnoi deyatel'nosti i soderzhanie oksida azota u rastushchikh gipokinezirovannykh i desimpatizirovannykh krys : dissertatsiya ... kandidata biologicheskikh nauk : 03.00 .13 [Effect of vagus nerve stimulation on cardiac output and nitric oxide content in growing hypokinesis and desympathetic rats (PhD Dissertation)]. Tatar State Humanitarian Pedagogical University. [in Russian].

[22] Khara, M. R., \& Dorokhina, A. M. (2009). Vplyv honadektomii na stan systemy oksydu azotu v shchuriv riznoi stati [The effect of gonadectomy on the status of the system of nitric oxide in rats of different sexes]. Visnyk naukovykh doslidzshen, (3), 78-80. [in Ukrainian].

[23] Dominguez-Rodriguez, A., Abreu-Gonzalez, P., Garcia-Gonzalez, M. J., Kaski, J. C., Reiter, R. J., \& Jimenez-Sosa, A. (2007). A unicenter, randomized, double-blind, parallel-group, placebo-controlled study of Melatonin as an Adjunct in patients with acute myocaRdial Infarction undergoing primary Angioplasty - The Melatonin Adjunct in the acute myocaRdial Infarction treated with Angioplasty (MARIA) trial: Study design and rationale. Contemporary Clinical Trials, 28(4), 532-539. https://doi.org/10.1016/i.cct.2006.10.007

[24] Reiter, R. J., \& Tan, D. X. (2003). Melatonin: a novel protective agent against oxidative injury of the ischemic/reperfused heart. Cardiovascular Research, 58(1), 10-19. https://doi.org/10.1016/ $\underline{\mathrm{s} 0008-6363(02) 00827-1}$ 